УДК 336.24

JEL Classification: G21, E58

ТАТАР М. С. ${ }^{1}$, КОЗЛОВСЬКА О. М. ${ }^{2}$

\title{
ВИЗНАЧЕННЯ ГЛИБИНИ КРИЗОВИХ ЯВИЩ БАНКІВСЬКИХ УСТАНОВ ТА РОЗРОБЛЕННЯ АНТИКРИЗОВИХ ЗАХОДІВ
}

DOI: $10.32620 /$ cher.2019.4.09

Постановка проблеми. У сучасних умовах розвитку економіки внаслідок економічної та політичної нестабільності значна кількість банків нездатні адекватно реагувати на зміни зовнішнього й внутрішнього середовища, внаслідок чого можуть потрапити у кризові ситуації, тому проблема визначення закономірностей та причин виникнення банківських криз, а також визначення можливостей їх подолання наразі $\epsilon$ вкрай актуальною. Метою статті $\epsilon$ розробка теоретико-методичних положень щодо закономірностей виникнення і протікання банківських криз й розробка практичних рекомендацій стосовно використання методів та інструментів, що дають змогу попередити та подолати кризові явища. Предмет дослідження - закономірності виникнення і протікання банківських криз й реалізація механізму антикризового управління діяльністю банків. Методи, використані 8 дослідженні: аналіз, синтез, абстрактно-логічний, порівняльний і статистичний, узагальнення та групування; системно-структурний, функціональний, інтегральний метод тощо. Гіпотеза дослідження. Наявність необхідності диференціації антикризових заходів в залежності від рівня кризового стану банку. Виклад основного матеріалу. Класифіковано чинники виникнення банківських криз. Розроблено комплексний підхід до діагностики кризових явищ у фінансовій діяльності банків. Визначено, що при виборі критеріїв та показників ідентифікації кризового стану банку повинен застосовуватися диференційований підхід, в основу якого покладено запропоновану систему показників, які мають відображати рівень достатності банківського капіталу, ліквідність, фінансову стійкість, ділову активість, показники прибутковості та ефективності банківської діяльності, тобто всі основні показники діяльності банку. Запропоновано превентивні та реактивні заходи в системі антикризового управління банками в залежності від рівня кризового стану банку. Оригінальність та практичне значення дослідження полягають в розробленні комплексного підходу до діагностики кризових явищ у діяльності банків на основі загальнодоступних даних, отриманих з оприлюдненої фінансової звітності банку. Висновки дослідження. Здійснено діагностування кризових явищ у діяльності АТ «ПРАВЕКС БАНК», розроблено комплекс превентивних та реактивних заходів антикризового управління фінансовою діяльністю банків, який являє собою сукупність методів та інструментів, спрямованих на досягнення визначених цільових орієнтирів, сформульованих залежно від стадії та глибини кризових явищ.

Ключові слова:

Антикризове управління, банківська криза, глибина кризи, класифікація, превентивні заходи, реактивні заходи, чинники виникнення банківських криз.

\section{DETERMINATION OF BANKING INSTITUTIONS CRISIS DEPTH AND DEVELOPMENT OF ANTI-CRISIS MEASURES}

Formulation of the problem. In the current economic environment, due to economic and political instability, a large number of banks are unable to adequately respond to changes of external and internal

${ }^{1}$ Татар Марина Сергіївна, канд. екон. наук, доцент кафедры «Фінанси», Національний аерокосмічний університет ім. М.Є. Жуковського «Харківський авіаційний інститут», м. Харків, Україна.

Tatar Maryna, Ph.D. in Economics, Associate professor of the Finance Department, National Aerospase University «Kharkiv Aviation Institute», Kharkiv, Ukraine.

ORCID ID: 0000-0002-1111-7103

e-mail: marina.sergeevna.tatar@gmail.com

${ }^{2}$ Козловська Ольга Михайлівна, магістрант спеціальності «Фінанси, банківська справа та страхування», Національний аерокосмічний університет ім. М. С. Жуковського «Харківський авіаційний інститут», м. Харків, Україна.

Kozlovskaya Olga, Master's degree of Finance, Banking and Insurance Specialty»of National Aerospase University «Kharkiv Aviation Institute», Kharkiv, Ukraine.

ORCID ID: 0000-0001-6458-1279

e-mail: kozlolga35@gmail.com 
environment, which can lead to crisis situations, so the problem of identifying patterns and causes of banking crises, as well as identifying opportunities to overcome them relevant. The aim of the research is development of theoretical and methodological provisions on the patterns of occurrence of banking crises and development practical recommendations on the use of methods and tools that can prevent and overcome crisis phenomena. The subject of the research is the regularity of the occurrence of banking crises and the implementation of the mechanism of banks anticrisis management. The methods of the research: analysis, synthesis, abstract and logical, comparative and statistical, generalization and grouping; structural, functional, integral method, etc. The hypothesis of the research. There is a need for differentiation of anti-crisis measures depending on the level of bank crisis state. The statement of basic materials. Factors of occurrence of banking crises are classified. The comprehensive approach to the diagnosis of crisis phenomena in the financial activity of banks has been developed. It is determined that in selecting the criteria and indicators for identifying the bank crisis state, differentiated approach should be used, which is based on the proposed system of indicators, which should reflect the level of bank capital adequacy, liquidity, financial stability, business activity, profitability and efficiency indicators of bank profitability and efficiency so the most important indicators of bank's activity. Preventive and reactive measures in the anticrisis management system of banks depending on the level of the crisis state are proposed. The originality and practical significance of the research is development a comprehensive approach to crisis diagnosis in bank operations on the bases of publicly available data obtained from the published financial statements of the bank. Conclusions and perspectives of further research. Crisis phenomena were diagnosed in the activity of PRAVEX BANK JSC, the complex of preventive and reactive measures of anti-crisis management of banks financial activity was developed, which is a set of methods and instruments aimed at achieving certain target targets, formulated according to crisis stage and depth.

\section{Keywords:}

crisis management, banking crisis, depth of crisis, classification, preventive measures, reactive measures, factors of banking crises occurrence.

\section{ОПРЕДЕЛЕНИЕ ГЛУБИНЫ КРИЗИСНЫХ ЯВЛЕНИЙ БАНКОВСКИХ УЧРЕЖДЕНИЙ И РАЗРАБОТКА АНТИКРИЗИСНЫХ МЕРОПРИЯТИЙ}

Постановка проблемыл. В современных условиях развития экономики вследствие экономической и политической нестабильности значительное количество банков неспособны адекватно реагировать на изменения внешней и внутренней среды, в результате чего могут попасть в кризисные ситуации, поэтому проблема определения закономерностей и причин возникновения банковских кризисов, а также определения возможностей их преодоления является крайне актуальной. Целью статьи является разработка теоретико-методических положений относительно закономерностей возникновения и протекания банковских кризисов и разработка практических рекомендаций по использованию методов и инструментов, позволяющих предупредить и преодолеть кризисные явления. Предмет исследования - закономерности возникновения и протекания банковских кризисов и реализация механизма антикризисного управления деятельностью банков. Memoды, исnользованные в исследовании: анализ, синтез, абстрактно-логический, сравнительный и статистический, обобщения и группировки; системно-структурный, функциональный, интегральный метод и др. Гипотеза исследования. Наличие необходимости дифференциации антикризисных мероприятий в зависимости от уровня кризисного состояния банка. Изложение основного материала. Классифицированы факторы возникновения банковских кризисов. Разработан комплексный подход к диагностике кризисных явлений в финансовой деятельности банков. Определено, что при выборе критериев и показателей идентификации кризисного состояния банка должен применяться дифференцированный подход, в основу которого положена предложенная система показателей, которые должны отражать уровень достаточности банковского капитала, ликвидность, финансовую устойчивость, деловую активность, показатели прибыльности и эффективности банковской деятельности, то есть все основные показатели деятельности банка. Предложены превентивные и реактивные мероприятия в системе антикризисного управления банками в зависимости от уровня кризисного состояния банка. Opuгинальность и практическое значение исследования заключаются в разработке комплексного подхода к диагностике кризисных явлений в деятельности банков на основе общедоступных данных, полученных из обнародованной финансовой отчетности банка. Выводы исследования. Осуществлено диагностирование кризисных явлений в деятельности АО «ПРАВЭКС БАНК», разработан комплекс превентивных и реактивных мероприятий антикризисного управления финансовой деятельностью банков, который представляет собой совокупность методов и инструментов, направленных на достижение определенных целевых ориентиров, сформулированных в зависимости от стадии и глуби- 
ны кризисных явлений.

\section{Ключевые слова:}

антикризисное управление, банковский кризис, глубина кризиса, классификация, превентивные меры, реактивные меры, факторы возникновения банковских кризисов.

Постановка проблеми. Надання банками повноцінних та якісних послуг і висока рентабельність банківських установ можливі тільки в умовах загальної фінансової стійкості економіки. Чим вище іiі стійкість, тим стабільніше банківська система. Банки ж, в свою чергу, можуть виступати причиною погіршення стану економіки. В останні роки тенденції розвитку банківського сектору демонструють різке зниження кількості банків внаслідок їх неплатоспроможності та банкрутства. Зазначене актуалізує необхідність визначення причин та закономірностей розвитку кризових явищ у банку й розроблення системи антикризового управління фінансовою стійкістю банків на основі визначення іiі принципів, функцій, завдань, пакета випереджальних антикризових інструментів та методів, 3 реалізацією яких $\epsilon$ можливим досягнення стійкого розвитку банків.

Аналіз останніх досліджень i публікацій. Проблемам діагностування кризи та антикризового управління у банку приділяється значна увага як вітчизняних, так i зарубіжних учених, зокрема таких як А. Алексеєнко, О. Барановський, I. Бланк, Г. Бондарева, В. Василенко, А. Гриценко, Ж. Довгань, О. Дзюблюк, Я. Жовтанецька, В. Корнєєв, В. Кочетков, С. Лєонов, В. Міщенко, С. Науменкова, Л. Перехрест, О.
Пернарівський, Л. Примостка, Ю. Ребрик, Л. Ситник, А. Степаненко, О. Терещенко, О. Шевцова, Н. Шелудько, Н. Шульга тощо. Проте залишаються недостатньо розробленими питання, пов'язані із визначеннм закономірностей виникнення криз, обгрунтуванням типів та глибини банківських криз, видів, моделей й механізму антикризового управління, методичного інструментарію діагностики кризових явищ у фінансовій діяльності банків, використанням превентивних і реактивних заходів 3 подолання кризових явищ в банку.

Метою статті є розробка теоретикометодичних положень щодо закономірностей виникнення і протікання банківських криз й розробка практичних рекомендацій стосовно використання методів та інструментів, що дають змогу попередити та подолати кризові явища.

Виклад основного матеріалу дослідження. Досліджуючи причини та фактори виникнення криз банку та банківської системи, слід зазначити, що вони в своїй більшості переважно є подібними, хоча можуть суттєво змінюватися, призводити до різних наслідків, мати різні масштаби, тривалість, форми прояву тощо. Чинники виникнення банківської кризи та механізми їх впливу на національну банківську систему представлено у табл. 1.

Т а б ли ц я 1

\section{Чинники виникнення банківської кризи та механізми їх впливу} на національну банківську систему

\begin{tabular}{|l|l|}
\hline \multicolumn{1}{|c|}{ Чинники } & \multicolumn{1}{|c|}{ Механізми впливу чинників на банківську систему } \\
\hline \multicolumn{1}{|c|}{1} & \multicolumn{1}{|c|}{2} \\
\hline $\begin{array}{l}\text { Несприятливі зміни цін на } \\
\text { основних для країни } \\
\text { міжнародних ринках }\end{array}$ & $\begin{array}{l}\text { Різке зниження цін на традиційні експортні товари або значне зрос- } \\
\text { тання вартості імпорту спричиняють втрату валютних доходів країни } \\
\text { загалом та їі експортерів, що зумовлює можливі збитки в обслуговую- } \\
\text { чих банках }\end{array}$ \\
\hline $\begin{array}{l}\text { Переважна частка коротко- } \\
\text { термінових зобов'язань у } \\
\text { структурі }\end{array}$ & $\begin{array}{l}\text { Висока питома вага короткотермінових зобов'язань, внаслідок необ- } \\
\text { хідності спрямування країною значних обсягів грошових коштів на } \\
\text { обслуговування зовнішнього боргу, накладає на банки суттєві обме- } \\
\text { ження щодо здійснення ними активних операцій }\end{array}$ \\
\hline $\begin{array}{l}\text { Реальне подорожчання націо-- } \\
\text { нальної валюти }\end{array}$ & $\begin{array}{l}\text { Подорожчання національної валюти в реальному вираженні призво- } \\
\text { дить до скорочення чистого експорту і формує девальваційні очіку- } \\
\text { вання, які можуть спровокувати вилучення депозитів вкладниками } \\
\text { банків }\end{array}$ \\
\hline $\begin{array}{l}\text { Високі процентні витрати за } \\
\text { внутрішнім боргом }\end{array}$ & $\begin{array}{l}\text { Зростання дохідності за внутрішніми зобов'язаннями з одного боку } \\
\text { свідчить про ріст процентних доходів, з іншої - про зниження ринко- } \\
\text { вої вартості придбаних цінних паперів }\end{array}$ \\
\hline
\end{tabular}




\begin{tabular}{|l|l|}
\multicolumn{2}{|c|}{ Продовження табл. 1} \\
\hline $\begin{array}{l}\text { Висока вартість запозичень на } \\
\text { ринку МБК }\end{array}$ & $\begin{array}{l}\text { Зростання процентної ставки в умовах перевищення строковості ак- } \\
\text { тивів над строковістю зобов’язань спричиняє підвищення вартості } \\
\text { фондування }\end{array}$ \\
\hline $\begin{array}{l}\text { Високий рівень ризиків у } \\
\text { банківській системі }\end{array}$ & $\begin{array}{l}\text { Недостатність наявного капіталу відносно прийнятих ризиків, слабке } \\
\text { покриття зобов’язань ліквідними активами, дисбаланс між валютними } \\
\text { активами та зобов’язаннями, висока частка прострочених позик у кре- } \\
\text { дитному портфелі банків можуть спричинити як банкрутство окремого } \\
\text { банку так і широкомасштабну банківську кризу }\end{array}$ \\
\hline $\begin{array}{l}\text { Сповільнення економічного } \\
\text { зростання }\end{array}$ & $\begin{array}{l}\text { Зниження темпів економічного зростання призводить до погіршення } \\
\text { платоспроможності країни, звуження можливостей позичальників } \\
\text { банку з обслуговування боргів }\end{array}$ \\
\hline Інфляція & $\begin{array}{l}\text { Запровадження політики активного подолання інфляції негативно } \\
\text { впливає на стан банківської системи }\end{array}$ \\
\hline Відкритість економіки & $\begin{array}{l}\text { Як свідчить практичних досвід багатьох країн, фінансова лібералізація } \\
\text { призводить до накопичення в банках «поганих» боргів }\end{array}$ \\
\hline $\begin{array}{l}\text { Валютизація активів } \\
\text { банківської системи (загалом } \\
\text { або окремих статей активів) }\end{array}$ & $\begin{array}{l}\text { Зміна частки активів, номінованих у іноземних валютах, свідчить про } \\
\text { недовіру банківської системи у стабільність національної валюти, а } \\
\text { зення (з врахуканням поправки на дохідність), - про недовіру насе- } \\
\text { лення }\end{array}$ \\
\hline
\end{tabular}

Джерело: узагальнено авторами на підставі [1]

Кризові явища окремого банку найбільш доцільно ідентифікувати на основі запропонованої системи основних аналітичних показників фінансового стану банку, які можуть слугувати сигнальними індикаторами для виявлення латентних, реальних та потенційних кризових явищ i загроз. Основні аналітичні показники для визначення інтегрального індикатору оцінки фінансового стану банку на прикладі АТ «ПРАВЕКС БАНК» наведено в табл. 2.
Отримані інтегральні індикатори фінансового стану АТ «ПРАВЕКС БАНК» наведено в табл. 3.

При виборі критеріїв та показників ідентифікації кризового стану банку повинен застосовуватися диференційований підхід, в основу якого покладено запропоновану систему показників, які мають відображати рівень достатності банківського капіталу, ліквідність, фінансову стійкість, ділову активість, показники прибутковості та ефективності банківської діяльності.

Т а б л и ц я 2

\section{Основні аналітичні показники для визначення інтегрального індикатору оцінки} фінансового стану АТ «ПРАВЕКС БАНК»

\begin{tabular}{|c|c|c|c|c|c|}
\hline \multirow{3}{*}{ Найменування показника } & & & & & \\
\hline & \multicolumn{5}{|c|}{ Значення за роками } \\
\hline & 2014 & 2015 & 2016 & 2017 & 2018 \\
\hline 1 & 2 & 3 & 4 & 5 & 6 \\
\hline \multicolumn{6}{|c|}{ Коефіцієнти оцінки рівня капіталізації банку } \\
\hline Коефіцієнт достатності капіталу & 2,1563 & 0,5988 & 0,9205 & 1,0035 & 0,5233 \\
\hline Коефіцієнт захищеності капіталу & 1,2428 & 0,3496 & 0,4307 & 0,4509 & 0,2237 \\
\hline Мультиплікатор капіталу & 9,7059 & 2,8501 & 3,9050 & 5,0508 & 2,2458 \\
\hline Коефіцієнт активності залучення коштів & 0,8970 & 0,6491 & 0,7439 & 0,8020 & 0,5547 \\
\hline $\begin{array}{l}\text { Питома вага депозитів клієнтів у зобов'язан- } \\
\text { нях }\end{array}$ & 0,8451 & 0,9329 & 0,9172 & 0,6972 & 0,9503 \\
\hline $\begin{array}{l}\text { Коефіцієнт активності залучення строкових } \\
\text { депозитів }\end{array}$ & 0,7581 & 0,6056 & 0,6823 & 0,5592 & 0,5272 \\
\hline $\begin{array}{l}\text { Ступінь використання платних пасивів бан- } \\
\text { ку }\end{array}$ & 0,7517 & 1,2067 & 0,8780 & 1,1119 & 1,2322 \\
\hline $\begin{array}{l}\text { Ефективність використання сукупних зо- } \\
\text { бов'язань }\end{array}$ & 0,6787 & 1,1348 & 0,8166 & 0,7753 & 1,1711 \\
\hline
\end{tabular}


Продовження табл. 2

\begin{tabular}{|c|c|c|c|c|c|}
\hline 1 & 2 & 3 & 4 & 5 & 6 \\
\hline \multicolumn{6}{|c|}{ Показники ліквідності } \\
\hline Коефіцієнт миттєвої ліквідності & 0,2844 & 0,1471 & 0,3054 & 0,3726 & 0,3469 \\
\hline $\begin{array}{l}\text { Коефіцієнт загальної ліквідності зобов'язань } \\
\text { банку }\end{array}$ & 1,1149 & 1,5405 & 1,3442 & 1,2469 & 1,8027 \\
\hline $\begin{array}{l}\text { Коефіцієнт відношення високоліквідних до } \\
\text { робочих активів }\end{array}$ & 0,2474 & 0,1016 & 0,2343 & 0,2589 & 0,2374 \\
\hline Коефіцієнт ресурсної ліквідності зобов'язань & 0,6787 & 1,1348 & 0,8166 & 0,7753 & 1,1711 \\
\hline $\begin{array}{l}\text { Коефіцієнт ліквідного співвідношення вида- } \\
\text { них кредитів і залучених депозитів }\end{array}$ & 0,6591 & 0,6104 & 0,3269 & 0,1875 & 0,5139 \\
\hline $\begin{array}{l}\text { Коефіцієнт генеральної ліквідності } \\
\text { зобов'язань }\end{array}$ & 0,3831 & 0,3262 & 0,4284 & 0,4052 & 0,5647 \\
\hline \multicolumn{6}{|c|}{ Показники фінансової стійкості банків } \\
\hline Коефіцієнт надійності & 0,1149 & 0,5405 & 0,3442 & 0,2469 & 0,8027 \\
\hline Коефіцієнт фінансового важеля & 8,7059 & 1,8501 & 2,9050 & 4,0508 & 1,2458 \\
\hline $\begin{array}{l}\text { Коефіцієнт участі власного капіталу у фор- } \\
\text { муванні активів - достатність капіталу }\end{array}$ & 0,1030 & 0,3509 & 0,2561 & 0,1980 & 0,4453 \\
\hline Коефіцієнт захищеності власного капіталу & 1,2428 & 0,3496 & 0,4307 & 0,4509 & 0,2237 \\
\hline \multicolumn{6}{|c|}{ Показники ділової активності } \\
\hline $\begin{array}{l}\text { Коефіцієнт активності залучення позичених } \\
\text { і залучених коштів }\end{array}$ & 0,8970 & 0,6491 & 0,7439 & 0,8020 & 0,5547 \\
\hline $\begin{array}{l}\text { Коефіцієнт активності залучення строкових } \\
\text { депозитів }\end{array}$ & 0,7581 & 0,6056 & 0,6823 & 0,5592 & 0,5272 \\
\hline $\begin{array}{l}\text { Коефіцієнт активності використання залуче- } \\
\text { них коштів у дохідні активи }\end{array}$ & 0,9717 & 1,3511 & 1,1955 & 1,1352 & 1,6225 \\
\hline $\begin{array}{l}\text { Коефіцієнт активності використання залуче- } \\
\text { них коштів у кредитний портфель }\end{array}$ & 0,5570 & 0,5694 & 0,2998 & 0,1307 & 0,4883 \\
\hline $\begin{array}{l}\text { Коефіцієнт активності спрямування у кре- } \\
\text { дитний портфель }\end{array}$ & 0,6591 & 0,6104 & 0,3269 & 0,1875 & 0,5139 \\
\hline Коефіцієнт дохідних активів & 0,8716 & 0,8770 & 0,8893 & 0,9104 & 0,9000 \\
\hline $\begin{array}{l}\text { Коефіцієнт кредитної активності інвестицій } \\
\text { у кредитний портфель }\end{array}$ & 0,4996 & 0,3696 & 0,2231 & 0,1048 & 0,2709 \\
\hline \multicolumn{6}{|c|}{ Показники прибутковості та ефективності банківської діяльності } \\
\hline $\begin{array}{l}\text { Прибутковість (збитковість) власного } \\
\text { капіталу }\end{array}$ & $-1,8759$ & $-0,4267$ & $-0,5373$ & $-0,0901$ & $-0,0605$ \\
\hline $\begin{array}{l}\text { Прибутковість (збитковість) статутного } \\
\text { капіталу }\end{array}$ & $-0,8700$ & $-0,7126$ & $-0,5837$ & $-0,0898$ & $-0,1156$ \\
\hline Ефективність роботи дохідних активів & 0,0541 & 0,0639 & 0,0858 & 0,0374 & 0,0968 \\
\hline Ефективність управління спредом & 0,0472 & 0,0561 & 0,0764 & 0,0341 & 0,0872 \\
\hline Дохідність 1 грн основного капіталу банку & 0,5218 & 0,4985 & 0,5139 & 0,2809 & 0,4709 \\
\hline Частка дохідних активів & 0,8716 & 0,8770 & 0,8893 & 0,9104 & 0,9000 \\
\hline $\begin{array}{l}\text { Пріоритетність напрямів використання } \\
\text { капіталу }\end{array}$ & 0,1284 & 0,1230 & 0,1107 & 0,0896 & 0,1000 \\
\hline $\begin{array}{l}\text { Дохідність використання ресурсної бази } \\
\text { банку }\end{array}$ & 0,1431 & 0,1716 & 0,1706 & 0,0986 & 0,2076 \\
\hline Дохідність роботи персоналу & $-289,56$ & $-315,29$ & $-394,43$ & $-87,62$ & $-117,51$ \\
\hline
\end{tabular}


Отримані інтегральні індикатори оцінки фінансового стану

АТ «ПРАВЕКС БАНК»

\begin{tabular}{|c|c|c|c|c|c|c|}
\hline Рік & $\begin{array}{c}\text { Інтеграль- } \\
\text { ний індика- } \\
\text { тор рівня } \\
\text { капіталіза- } \\
\text { ції банку } \\
\text { (Ірк) }\end{array}$ & $\begin{array}{c}\text { Інтеграль- } \\
\text { ний індика- } \\
\text { тор } \\
\text { ліквідності } \\
\text { (Іл) }\end{array}$ & $\begin{array}{c}\text { Інтегральний } \\
\text { індикатор } \\
\text { фінансової } \\
\text { стійкості (Іфс) }\end{array}$ & $\begin{array}{c}\text { Iнтегральний } \\
\text { індикатор } \\
\text { ділової актив- } \\
\text { ності (Іда) }\end{array}$ & $\begin{array}{c}\text { Інтегральний } \\
\text { індикатор } \\
\text { прибутко-вості } \\
\text { (Іп) }\end{array}$ & $\begin{array}{c}\text { Інтеграль- } \\
\text { ний інди- } \\
\text { катор } \\
\text { оцінки } \\
\text { фінансо- } \\
\text { вого стану } \\
\text { банку }\end{array}$ \\
\hline 2014 & 0,5128 & 0,4438 & 0,1756 & 0,3861 & 0,5283 & 0,4725 \\
\hline 2015 & 0,3117 & 0,3782 & 0,2693 & 0,3950 & 0,5599 & 0,3773 \\
\hline 2016 & 0,3642 & 0,5411 & 0,1067 & 0,3378 & 0,6595 & 0,5370 \\
\hline 2017 & 0,2849 & 0,4495 & 0,2214 & 0,1122 & 0,1823 & 0,1643 \\
\hline 2018 & 0,1765 & 0,8833 & 0,1262 & 0,3119 & 0,3848 & 0,3341 \\
\hline
\end{tabular}

Для оцінки інтегрального індикатора проблемності та кризового стану банків запропоновано визначати не лише агреговані показники за зазначеними складовими оцінки рівня кризового стану, але й визначити зважені значення показників з урахуванням їх вагових значень (табл. 4). На основі комплексного аналізу та оцінки кризового стану банків України України в розрізі окремих іiі складових визначено інтегральний індикатор як суму добутків інтегральних індикаторів кожної із їі складових та вагових коефіцієнтів, які визначають ступінь внеску конкретних показників в інтегральний індекс.

Інтегральний індикатор оцінки кризового стану банків (Ікс) пропонуємо визначати за формулою:

$$
\begin{aligned}
I \kappa c=I p \kappa \times m_{p \kappa}+I J \times & m_{l}+I \phi c \times m_{\phi c}+I \partial a \times \\
& \times m_{\partial a}+I n \times m_{n}
\end{aligned}
$$

де $I_{n}-$ значення інтегрального індикатора визначеної групи показників (Ірк, Iл і т. д.); $m_{n}$ - значення вагового коефіцієнта визначеної групи показників $\left(m_{p \kappa}, m_{l}\right.$ і т. д. $)$.

Значення вагових коефіцієнтів $m n$ наведені у табл. 4. Сумарне значення вагових коефіцієнтів інтегрального індикатора дорівнює 1, а вагові значення інтегральних показників визначених груп сформовані 3 урахуванням їх пріоритетності i значимості впливу на виникнення кризових явищ.

\section{Вагові коефіціснти в межах груп показників}

Т а б ли ц я 4

\begin{tabular}{|l|c|c|}
\hline \multicolumn{1}{|c|}{ Назва інтегрального індикатора } & $\begin{array}{c}\text { Умовне позначення } \\
\text { вагового коефіцієнта }\end{array}$ & Значення \\
\hline Інтегральний індикатор рівня капіталізації банку $($ Ірк) & $m_{\text {рк }}$ & 0,19 \\
\hline Інтегральний індикатор ліквідності (Iл) & $m_{\text {Л }}$ & 0,25 \\
\hline Інтегральний індикатор фінансової стійкості $(I \phi c)$ & $m_{\phi c}$ & 0,16 \\
\hline Інтегральний індикатор ділової активності $(I \partial a)$ & $m_{\text {да }}$ & 0,10 \\
\hline Інтегральний індикатор прибутковості $(I n)$ & $m_{\text {п }}$ & 0,30 \\
\hline
\end{tabular}

Джсерело: розроблено авторами на підставі $[3,5]$

На підставі отриманих розрахункових значень коефіцієнтів здійснюється порівняння їх значень 3 оптимальними та розрахунковими і визначається тип та глибина кризи, яка може бути:

- потенційною - в умовах стабільності функціонування банків;

- прихованою (латентною) - у разі наявних деструктивних значень аналітичних коефіцієнтів, що потребує розробки антикризових програм, які базуються на використанні превентивних методів антикризового управління банківською діяльністю;

- гострою - у випадку критичних значень більшості аналітичних коефіцієнтів, що підтверджують проблемність у всіх ключових сферах банківського бізнесу та вимагають 
розробки програм й застосування реактивних методів антикризового менеджменту;

- критичною - у разі настання ситуації глибокої фінансової неспроможності та нежиттєздатності й критичного значення аналітичних коефіцієнтів.

Запропонований підхід доцільно застосовувати як для виявлення кризи в банківській системі, так і в окремих установах 3 врахуванням їі глибини, рівня й типу. Чис- лові значення інтегрального індикатора оцінки кризового стану банків доцільно диференціювати залежно типу та глибини кризи у визначеному діапазоні в рамках 4 рівнів (табл. 5).

Отримані значення інтегрального індикатору оцінки кризового стану та рівень кризового стану АТ «ПРАВЕКС БАНК» представлено в табл. 6.

\section{Шкала градації рівнів кризового стану банків України}

Т а б ли ц я 5 з урахуванням типу та глибини кризи

\begin{tabular}{|c|c|c|}
\hline $\begin{array}{c}\text { Значення } \\
\text { інтегрального } \\
\text { індикатора } \\
\text { кризового стану }\end{array}$ & $\begin{array}{l}\text { Рівень } \\
\text { кризового } \\
\text { стану }\end{array}$ & Характеристика \\
\hline $0,6-0,79$ & задовільний & $\begin{array}{l}\text { наявність ознак потенційної кризи в умовах стабільності } \\
\text { функціонування банків і системи; }\end{array}$ \\
\hline $0,4-0,59$ & небезпечний & $\begin{array}{l}\text { прихована (латентна) криза. Наявні деструктивні значення } \\
\text { аналітичних коефіцієнтів, що потребує розробки антикризових } \\
\text { програм, які базуються на використанні превентивних методів } \\
\text { антикризового управління банківською діяльністю; }\end{array}$ \\
\hline $0,2-0,39$ & критичний & $\begin{array}{l}\text { гостра переробна криза. Наявні критичні значення більшості } \\
\text { аналітичних коефіцієнтів, що підтверджують проблемність у } \\
\text { всіх } 6 \text { ключових сферах банківського бізнесу та вимагають } \\
\text { розробки програм й застосування реактивних методів антикри- } \\
\text { зового менеджменту; }\end{array}$ \\
\hline $0-0,19$ & $\begin{array}{l}\text { катастрофіч- } \\
\text { ний }\end{array}$ & $\begin{array}{l}\text { глибока (часто - гостра непереробна) фінансова неспро- } \\
\text { можність та нежиттєздатність. Критичні значення аналітичних } \\
\text { коефіцієнтів. Повна втрата здатності функціонувати у не- } \\
\text { стабільних умовах, ознаки неплатоспроможності та нежит- } \\
\text { тєздатності на локальному й системному рівнях }\end{array}$ \\
\hline
\end{tabular}

Джерело: розроблено авторами на підставі $[3,5]$

Т а б ли ц я 6

\section{Інтегральний індикатор оцінки кризового стану АТ «ПРАВЕКС БАНК»}

\begin{tabular}{|r|c|c|}
\hline \multicolumn{1}{|c|}{ Рік } & $\begin{array}{c}\text { Інтегральний індикатор } \\
\text { кризового стану банку }\end{array}$ & Рівень кризового стану \\
\hline 2014 & 0,4725 & небезпечний \\
\hline 2015 & 0,3773 & критичний \\
\hline 2016 & 0,5370 & небезпечний \\
\hline 2017 & 0,1643 & катастрофічний \\
\hline 2018 & 0,3341 & критичний \\
\hline
\end{tabular}

Якщо значення інтегрального індикатору оцінки кризового стану банку знаходиться у діапазоні [0,8-1] то це означає, що банку криза не загрожує.

Таким чином, проведено розрахунки основних аналітичних показників рівня кризового стану в розрізі п'яти груп 3 позицій виявлення проблемних аспектів діяльності й подальшого застосування інструментарію антикризового управління.

Для підвищення ефективності антикризового управління банків доцільно використовувати удосконалену процедуру антикризового менеджменту, яка дозволяє інтегрувати у собі функціональні та інституційні аспекти цього процесу і яку пропонується реалізовувати у такому порядку (рис. 1). 
Етап 1. Ідентифікація рівня кризового стану банку, яка грунтується на коефіцієнтному аналізі діяльності банку у розрізі оцінки стану ліквідності, структури та якості активів, рівня капіталізації тощо.

Етап 2. Аналітична оцінка масштабів кризи та ймовірних втрат банку від неї. На цьому етапі застосовується як інструмент стрес-тестування 3 метою оцінки потреби у потенційній докапіталізації 3 урахуванням окремих ризиків діяльності банку (кредитного, валютного та ін.).

Етап 3. Застосування операційних заходів, спрямованих на забезпечення необхід- ного рівня ліквідності, покращення якості активів, збільшення капіталу (мають бути реалізовані у вищезазначеній послідовності).

Етап 4. Аналіз ефективності застосування процедури антикризового менеджменту банківської установи, який базується на порівнянні витрат на реалізацію антикризових заходів та наявних фінансових ресурсів акціонерів.

Етап 5. Вжиття коригуючих заходів 3 метою підвищення ефективності антикризового менеджменту банку та усунення виявлених недоліків.

Етап 1. Ідентифікація кризового стану банку

Етап 2. Оцінювання рівня кризового стану банку, масштабів кризи та ймовірних втрат банку від неї

\begin{tabular}{|c|}
\hline Етап 1. Ідентифікація кризового стану банку \\
\hline $\begin{array}{c}\text { Етап 2. Оцінювання рівня кризового стану банку, масштабів кризи та } \\
\text { ймовірних втрат банку від неї }\end{array}$ \\
\hline $\begin{array}{c}\text { Етап 3. Розробка превентивних або реактивних заходів в залежності } \\
\text { від рівня кризового стану банку }\end{array}$ \\
\hline Етап 4. Аналіз ефективності застосування \\
процедури антикризового менеджменту \\
\hline Етап 5. Вжиття коригуючих заходів \\
\hline
\end{tabular}

Рисунок 1 - Процедура реалізації антикризового менеджменту в банківських установах

Джерело: розроблено авторами на підставі [2]

Залежно від масштабу кризових явищ та рівня кризи окремих банків диференціюються конкретні антикризові заходи. Виокремлено основні етапи впливу кризових чинників на функціонування банківської установи та адекватні кожному етапу антикризові заходи (табл. 7).

В процесі впровадження антикризового управління діяльністю банків використовуються основні методи превентивного і реактивного антикризового менеджменту. Впровадження комплексу заходів в рамках попередження (мінімізації) негативних проявів кризи в умовах стабільності банківської діяльності грунтується на тому, що антикризове управління в банку повинно мати місце не лише тоді, коли криза уже наступила, а носити превентивний характер. Відповідно система заходів в частині попереджувального (превентивного) антикризового управління диференціюється залежно обраного методичного інструментарію. Зокрема, деякі науковці виокремлюють такі методи запобігання проявам кризи у банківській сфері як: антикризовий моніторинг; аналіз чутливості банку до кризи; антикризові організаційні стратегії; внутрішній аналіз і контроль; антикризове планування; система зниження ризиків; підвищення безпеки банківського бізнесу; залучення незалежних аудиторів [6]. 
Т а б ли и я 7

Диференціація антикризових заходів в залежності від рівня кризи банку

\begin{tabular}{|c|c|}
\hline Етап & Форми прояву та заходи \\
\hline Етап превентивний & $\begin{array}{l}\text { Основними формами прояву є погіршення показників системи ранньої } \\
\text { ідентифікації кризового станку банківської установи, що грунтується на } \\
\text { аналізі визначених коефіцієнтів. На цьому етапі проводиться дослідження } \\
\text { потенційних джерел виникнення проблем, оцінка величини та якості ри- } \\
\text { зиків, притаманних діяльності банку. } 3 \text { метою оцінки ймовірних масштабів } \\
\text { прояву кризи та величини майбутніх втрат (зокрема, зниження капіталу) } \\
\text { проводиться стрес-тестування окремих ризиків діяльності банку. Також } \\
\text { розробляються та актуалізуються плани управління банком у випадку кри- } \\
\text { зової ситуації. } \\
\text { Заходи, що вживаються на цьому етапі, та інструменти, які використо- } \\
\text { вуються, мають більш аналітичний характер: стрес-тестування; система } \\
\text { ранньої ідентифікації кризового станку банку, що базується на аналізі } \\
\text { коефіцієнтів; плани управління банком у випадку кризової ситуації. }\end{array}$ \\
\hline $\begin{array}{l}\text { Етап виникнення } \\
\text { кризового стану }\end{array}$ & $\begin{array}{l}\text { Характерними ознаками цього етапу є значний неконтрольований } \\
\text { відтік коштів вкладників та інших кредиторів, зменшення лімітів кредиту- } \\
\text { вання банку контрагентами на міжбанківському ринку. Також відбувається } \\
\text { суттєве зниження якості активів, зумовлене погіршенням фінансового ста- } \\
\text { ну позичальників, простроченням термінів виконання кредитних зо- } \\
\text { бов’язань, зниженням вартості забезпечення. Відображенням вказаного } \\
\text { процесу є потреба у доформуванні резервів. Також для зазначеного етапу } \\
\text { характерне значне зниження показників економічних нормативів діяль- } \\
\text { ності банку та понесення суттєвих збитків. } \\
\text { Заходи, що вживаютьяя на цьому етапі, та інструменти, які використо- } \\
\text { вуються, мають на меті усунення ознак кризового стану банку. Реструкту- } \\
\text { ризація заборгованості перед великими кредиторами банку, зокрема за } \\
\text { єврооблігаціями, пролонгація депозитів, реструктуризація прострочених } \\
\text { кредитів, залучення додаткового забезпечення, оптимізація витрат (за } \\
\text { рахунок скорочення філій та відділень, зменшення кількості персоналу), } \\
\text { зниження розміру відвернень під час розрахунку регулятивного капіталу } \\
\text { банку (вкладення в нематеріальні активи), залучення субординованого } \\
\text { капіталу, конвертація боргових зобов'язань у капітал. }\end{array}$ \\
\hline $\begin{array}{c}\text { Етап активної } \\
\text { протидії поширенню } \\
\text { кризи }\end{array}$ & $\begin{array}{l}\text { Основними формами прояву є нездатність задовольняти вимоги вклад- } \\
\text { ників та інших кредиторів, порушення встановлених регулятором еко- } \\
\text { номічних нормативів діяльності банку, обсяг проблемної заборгованості } \\
\text { досягає } 15-40 \% \text { кредитного портфеля, стрімке зниження регулятивного } \\
\text { капіталу протягом місяця (понад } 20 \% \text { ). } \\
\text { Заходи, що вживаються на цьому етапі, та інструменти, які використо-- } \\
\text { вуються, спрямовані на комплексне подолання кризових явищ та усунення } \\
\text { загрози платоспроможності банківської установи: залучення } \\
\text { стабілізаційного кредиту від регулятора для підтримки ліквідності, ак- } \\
\text { тивізація претензійно-позовної роботи, продаж портфелів проблемних } \\
\text { кредитів, розроблення Програми фінансового оздоровлення (основний } \\
\text { пункт такої програми забезпечення докапіталізації банку), збільшення ста- } \\
\text { тутного капіталу банку (у випадку недостатності коштів у акціонерів } \\
\text { розглядається можливість продажу банку новому інвестору), оцінка } \\
\text { ймовірності призначення тимчасової адміністрації у банку. }\end{array}$ \\
\hline
\end{tabular}

Джерело: узагальнено авторами на підставі [4]

До основних інструментів превентивного управління можна віднести моделювання розвитку подій, технологію сценарного розвитку, індикаторний підхід раннього попередження, аналіз критичних зв'язків, SWOT-аналіз тощо. Превентивна модель антикризового управління вважається доцільною в контексті дотримання позицій економічності, оскільки витрати на запобігання кризі значно менші, ніж витрати на $\dddot{1}$ подолання й мінімізацію [4].

Отже, превентивний менеджмент реалізовується на стадіях потенційної та латент- 
ної кризи. Поряд 3 тим, зважаючи на відсутність чітко окреслених меж між стадіями кризи, раціоналізується необхідність здійснення превентивного контролю для виявлення так званих "тривожних" симптомів і проведення попереджувальних заходів, основна мета яких відновлення стабільного функціонування банку i повернення до методів традиційного управління.

Реактивна модель антикризового управління - це система заходів, спрямованих на по-
Отже, реактивне антикризове управління має низку таких характеристик: по-перше, реалізується в умовах наявної переборювальної чи непереборювальної кризи, по-друге, вимагає розробку й реалізацію невідкладних заходів, по-третє, має динамічний характер й обмежені часові рамки, по-четверте, грунтується на специфічних методах управління.

Методологія реактивного антикризового менеджменту базується на ситуаційному аналізі, який розглядає будь-яку ситуацію в динаміці i грунтується на використанні взаємоузгоджених методичних підходів. Такий підхід передбачає розробку сценаріїв й наслідків на основі стратегічних альтернатив із застосуванням специфічних методів та інструментів. Методологічні засади такого управління грунтуються на розробці програм виходу із реальної кризи 3 позицій мінімізації втрат та нейтралізації ризиків й загроз.

Систему превентивних та реактивних заходів антикризового управління фінансовою діяльністю банків доцільно представити у вигляді цільових орієнтирів, методів, інструментів (табл. 8).

Т а б ли ц я 8

Система превентивних та реактивних заходів антикризового управління фінансовою діяльністю банків

\begin{tabular}{|c|c|c|c|c|}
\hline $\begin{array}{c}\text { Система } \\
\text { заходів }\end{array}$ & $\begin{array}{c}\text { Рівень кри- } \\
\text { зового стану } \\
\text { та вид кризи }\end{array}$ & Цільові орієнтири & Інструменти & Методи \\
\hline $\begin{array}{c}\text { Система пре- } \\
\text { вентивних за- } \\
\text { ходів }\end{array}$ & $\begin{array}{l}\text { Задовільний } \\
\text { i небезпеч- } \\
\text { ний рівень } \\
\text { кризового } \\
\text { стану. } \\
\text { Потенційна } \\
\text { криза і при- } \\
\text { хована (ла- } \\
\text { тентна) кри- } \\
\text { за }\end{array}$ & $\begin{array}{l}\text { Підтримка ліквідності і } \\
\text { платоспроможності } \\
\text { Попередження ризиків } \\
\text { у діяльності банків } \\
\text { Недопущення } \\
\text { (мінімізація) втрат } \\
\text { Підвищення безпеки } \\
\text { банківського бізнесу } \\
\text { Профілактика потен- } \\
\text { ційних кризових ситу- } \\
\text { ацій }\end{array}$ & $\begin{array}{l}\text { Моделювання ро- } \\
\text { звитку подій } \\
\text { Технологія сце- } \\
\text { нарного розвитку } \\
\text { Індикаторний } \\
\text { підхід i системи } \\
\text { раннього попере- } \\
\text { дження } \\
\text { Аналіз критичних } \\
\text { зв’язків }\end{array}$ & $\begin{array}{l}\text { Антикризовий } \\
\text { моніторинг } \\
\text { Аналіз чутливості } \\
\text { банків до кризи } \\
\text { Формування анти- } \\
\text { кризових стратегій } \\
\text { Антикризове пла- } \\
\text { нування } \\
\text { Стрес-тестування }\end{array}$ \\
\hline $\begin{array}{l}\text { Система реак- } \\
\text { тивних заходів }\end{array}$ & $\begin{array}{l}\text { Критичний і } \\
\text { катастрофі } \\
\text { чний рівні } \\
\text { кризового } \\
\text { стану. } \\
\text { Глибока } \\
\text { (гостра пе- } \\
\text { реробна) } \\
\text { криза. } \\
\text { Гостра непе- } \\
\text { реробна кри- } \\
\text { за. }\end{array}$ & $\begin{array}{l}\text { Вихід із кризи та їі ло- } \\
\text { калізація } \\
\text { Відновлення фінансової } \\
\text { стабільності банку } \\
\text { Відновлення докризо- } \\
\text { вих параметрів ведення } \\
\text { банківського бізнесу } \\
\text { Запобігання банкрут- } \\
\text { ству }\end{array}$ & $\begin{array}{l}\text { Планування й про- } \\
\text { гнозування } \\
\text { Умови санаційного } \\
\text { кредитування } \\
\text { План реструктури- } \\
\text { зації } \\
\text { План реорганізації }\end{array}$ & $\begin{array}{l}\text { Санація } \\
\text { Антикризова реор- } \\
\text { ганізація } \\
\text { Антикризова ре- } \\
\text { структуризація } \\
\text { Ліквідація }\end{array}$ \\
\hline
\end{tabular}

Джерело: узагальнено авторами на підставі $[4,6]$

систем альтернативного реагування на кризові явища з врахуванням їх типів та глибини. Реактивне антикризове управління найчастіше здійснюється 3 використанням санаційних, реструктуризаційних, реорганізаційних й ліквідаційних методів управління в умовах як фінансових, так і часових обмежень.

Висновки та перспективи подальших досліджень. Таким чином, здійснено діагностування кризових явищ у діяльності АТ «ПРАВЕКС БАНК», розроблено комплекс превентивних та реактивних заходів антикризового управління фінансовою діяльністю 
банків, який являє собою сукупність методів та інструментів, спрямованих на досягнення визначених цільових орієнтирів, сформульованих залежно від стадії та глибини кризових явищ. У межах подальших досліджень планується здійснити оцінювання ефективності застосування процедури антикризового менеджменту банку.

\section{Література}

1. Любіч О. О., Бортніков Г. П. Банківська криза в Україні: причини, особливості, подолання. Збірник наукових пращь Національного університету державної податкової служби Украӥни. 2016. № 1. С. 118130.

2. Жовтанецька Я. В. Механізм антикризового управління діяльністю банків. Бізнес Інформ. 2015. № 6. С. 187-192.

3. Жовтанецька Я. В. Комплексний підхід до діагностики кризових явищ у фінансовій діяльності банків України. Сочіально-економічні проблеми сучасного періоду Украӥни. 2017. Вип. 3. С. 36-41.

4. Жовтанецька Я. В. Превентивні та реактивні заходи в системі антикризового управління банками. Wschodnioeuropejskie Czasopismo Naukowe (Warszawa,Polska). 2017. № 4 (20). C. 89-95.

5. Лєонов С. В., Афанасьєва О. Б. Концептуальні засади побудови багаторівневої системи антикризового управління банківською діяльністю. Ефективна економіка: електрон. наук. фахове вид. 2011. № 5 . URL: http://www.economy.nayka.com.ua.

6. Кузнєцова А. Я., Джулай В. О. Антикризове управління в банківському секторі економіки України: стан, проблеми $i$ перспективи: монографія. Київ: УБС НБУ, 2012. $202 \mathrm{c}$.

\footnotetext{
Стаття надійшла

до редакції : 13.10.2019 p.
}

7. Фінансова звітність AT «ПРАВЕКС БАНК». Офіційний веб-сайт АТ «ПРАВЕКС БАНК» URL: https://www.pravex.com.ua

\section{References}

1. Lyubich O. O. \& Bortnikov G. P. (2016) Banking crisis in Ukraine: causes, features, overcoming. Proceedings of the National University of State Tax Service of Ukraine, 1, 118130.

2. Zhovtanetska Y. V. (2015) The mechanism of anti-crisis management of banks. Business Inform, 6, 187-192.

3. Zhovtanetska Y. V. (2017) Complex approach to the diagnosis of crisis phenomena in the financial activity of Ukrainian banks. Socioeconomic problems of the modern period of Ukraine, 3, 36-41.

4. Zhovtanetska Y. V. (2017) Preventive and Reactive Measures in the Bank Crisis Management System // Wschodnioeuropejskie Czasopismo Naukowe (Warszawa, Polska), 4 (20), 89-95.

5. Leonov S. V. \& Afanasieva O. B. (2011) Conceptual foundations for the construction of a multi-level system of crisis management of banking activities. Effective Economics, 5 Retrieved from: http://www.economy.nayka.comua

6. Kuznetsova A. Y \& Dzhulai V. A. (2012) Anti-crisis management in the banking sector of Ukrainian economy: state, problems and prospects. UBS NBU, 202.

7. Financial statements of PRAVEX BANK JSC. Official site of PRAVEX BANK JSC Retrieved from: https://www.pravex.com.ua

$$
\begin{aligned}
& \text { Стаття прийнята } \\
& \text { до друку: 27.12.2019 p. }
\end{aligned}
$$

Бібліографічний опис для цитування :

Татар М. С. Визначення глибини кризових явищ банківських установ та розроблення антикризових заходів / М. С. Татар, О. М. Козловська // Часопис економічних реформ. - 2019. - № 4 (36). C. $65-75$. 